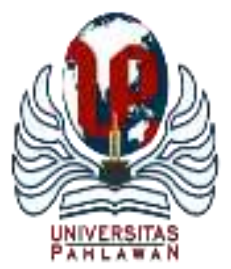

Edukatif : Jurnal Ilmu Pendidikan Volume 3 Nomor 6 Tahun 2021 Halm 4532 - 4540

EDUKATIF: JURNAL ILMU PENDIDIKAN

Research \& Learning in Education

https://edukatif.org/index.php/edukatif/index

\title{
The Future of Nonnative Teachers of English
}

\author{
Nining Ismiyani \\ Sociology Education Department, Universitas Tanjungpura, Indonesia \\ E-mail : niningismiyani@untan.ac.id
}

\begin{abstract}
Abstrak
Guru bahasa Inggris bukan penutur asli yang sering diklaim kurang kompeten dan berkualitas dibandingkan dengan rekan-rekan penutur asli mereka. Tulisan ini bertujuan untuk mengelaborasi bahwa identitas guru bahasa Inggris bukan lagi menjadi masalah terutama dalam hal profesi guru bahasa Inggris. Metodologi berbasis literatur digunakan dalam makalah ini. Diskusi dibagi menjadi dua bagian; bagian pertama membahas status dan identitas guru bukan penutur asli berbahasa Inggris dan bagian kedua menggambarkan tindakan untuk kepercayaan diri guru bahasa Inggris bukan penutur asli sebagai bahasa internasional. Sebagai kesimpulan, Pengajaran Bahasa Inggris harus menekankan pada kualitas guru dari kompetensi mengajar bahasa Inggris daripada identitas bukan penutur asli yang tidak relevan. Selanjutnya, aksi-aksi berupa pelatihan dan usaha lainnya perlu dilakukan oleh guru bukan penutur asli untuk meningkatkan kinerja mereka dalam pengajaran bahasa Inggris untuk meningkatkan kepercayaan diri mereka terhadap status mereka di ELT dan untuk dapat bersaing secara internasional.
\end{abstract}

Kata Kunci: Penutur asli, penutur tidak asli, guru, identitas, pengajaran Bahasa Inggris

\section{Abstract}

This paper discusses nonnative teachers of English who are often claimed to be less competent and qualified compared to their native counterparts. The aim of this paper is to elaborate that the identity of the teachers of English shall no longer be problematic in a matter of English Language teaching profession. The literaturebased methodology was employed in this paper. The discussion is divided into two sections; the first part discusses the status and identity of nonnative English-speaking teachers and the second part delineates the actions for self-confidence of nonnative teachers of English as an international language. To conclude, Teaching English must emphasize on the teacher's quality of the English teaching competence rather than the irrelevant nonnative identity. Furthermore, actions need to be executed by Nonnative English-speaking teachers (NNESTs) to enhance their performance in English language teaching in order to increase their selfconfidence of their status in ELT and to be able to internationally compete.

Keywords: Native, Nonnative, teacher, Identity, English Teaching.

Copyright (c) 2021 Nining Ismiyani

$\checkmark$ Corresponding author

Email : niningismiyani@untan.ac.id

DOI $\quad:$ https://doi.org/10.31004/edukatif.v3i6.1243

ISSN 2656-8063 (Media Cetak)

ISSN 2656-8071 (Media Online) 


\section{INTRODUCTION}

Being a teacher is not easy. I believe nobody would argue such a statement. It seems that a teacher has to satisfy all expectations not only from the students as the target of an expectedly successful teachinglearning process, but also from the professional superiors such as the headmaster, dean, rector, and the educational departments authorizing the teaching sector in the country. As a result, being a teacher does not only mean knowledgeable, but also be mentally ready to face unsettling situation during his/her profession time. Facing the reality that being a teacher is already hard, I find that being a so-called nonnative teacher of English is even harder. Nonnative English-speaking teachers (NNESTs) must face a dilemma to teach this global language. Unlike teaching other subjects in which anyone all over the world who is competent can merely teach them, teaching English means teaching the language that guides people to communicate to anyone from any country and lead to an advancement of technology, business, industry, and other promising fields, so that it is assumed as best taught by the owners, the so-called native speakers of English. Popular institutions to mention private English courses and international schools or colleges in Asia tend to hire Native English Teachers (NESTs) to teach English in their institutions (Kasai, M., Lee, J. A., \& Kim, 2011; Kurniawati \& Rizki, 2018).

English keeps becoming globalized to say it is continuously spoken worldwide. Not only English is communicated as the first language of Englishmen, Americans, Australians, Canadians or New Zealanders, it has also been growing for years as the second language of Malaysians, Singaporeans, Indians, and other nations from outer circle countries. English is also the most favorite foreign language learned by people of expanding countries such as Indonesia, China, Philippines and most of other developing countries where English mainly plays internationally with only few in country-uses. In addition, it is an undeniable fact that nonnative speakers of English outnumber their native counterparts (Moussu \& Llurda in Mauludin, 2015). This condition has triggered a rising number of English learners globally and as a consequence, has increased the demand of English teachers who also come from these non-inner circles.

As English is spread all over the world, nonnative English teachers are inevitably flourishing for the demand of mastering English. These teachers definitely contribute a lot to the increasing number of World English speakers. However, the status of these English teachers to be 'nonnative' is frequently questioned for their credibility and quality in teaching English and is often compared to their Native English teacher colleagues. Nonnative teachers of English are often claimed to be less competent in teaching English than their native counterparts (Canagarajah in Sadeghpour \& Sharifian, 2019). Moreover, many studies have shown that Inner Circle Englishes, particularly American and British English still have overpowering support to be used and therefore taught worldwide (Ahn, 2013; Khatib \& Monfared, 2017; Sharifian, 2014). According to Sharifian $(2014$, p. 35), the main challenges are 'Whose culture and which variety should be taught?'. Wrong perception of NNES often results in unfair hiring recruitments.

NNESTs are really challenged for their quality and credibility in teaching this global language as they are generally admitted to be less competent and effective in teaching English. Therefore, any efforts must be performed to boost the quality of these nonnative teachers of English so that they can prove that they are qualified and professional in English language teaching profession.

This article discusses the status and identity of nonnative English-speaking teachers (NNEST) as well as the actions that may help these so-called nonnative teachers increase their competence and self-confidence of their status as language professionals. Tsou \& Chen (2019) support that competencies of NNEST have become a significant matter of discussion. Various investigations have been conducted concerning the issue of NEST and NNEST. However, only a few of them has raised the issue in Asia, especially in Indonesia (Nguyen, 2017; Sun, 2014; Tajeddin \& Adeh, 2016). The field of NEST and NNEST is rarely discussed in the Indonesian Journals that this study was intended to fill the gap. 


\section{METHOD}

In writing this paper, the literature-based methodology was employed. A credible source was mainly investigated and explored in the research to mention "Native speakers', English and ELT: changing perspectives" from Llurda (2016). This written source was published in Routledge, a British multinational publisher claimed to be the largest global academic publisher within humatities and sciences (Publishing With Us - Routledge, 2016).

Books and journals as the literature related to NESTs and NNESTs were also reviewed including their strengths, weaknesses, challenges as well as the actions to improve the quality of NNESTs. Literature-based research is the process of collecting and incorporating, evaluating and analysing as well as formulating writers's arguments, in which the whole process is constantly interrelated (Barrientos in Kurniawati \& Rizki, 2018).

\section{RESULTS AND DISCUSSION}

\section{Status and identity of nonnative-english speaking teachers}

The issues of the dichotomy between native and nonnative teachers of English have been the ongoing topics in many writings of some concerned linguists such as Medgyes (in Sadeghpour \& Sharifian, 2019), Llurda (2016), Braine (2010), and Sharifian (2014). It shows that the interest and attention given especially to those teachers who come from what Kachru, the original founder of the terms "inner, outer, and expanding circles" (1986) calls the expanding circle countries, keep growing and will certainly contribute to the positive development of understanding towards NNESTs.

We cannot avoid hearing that people judge us, the teachers from international varieties of English, as less competent in English communication than the so-called native-speaking teachers of English. According to Medgyes (in Sadeghpour \& Sharifian, 2019) the native and nonnative distinction is accepted in general. Braine (2010) also found that a nonnative speaker of a language is always defined against a native speaker of that language. However, we cannot actually enjoy such dichotomy and accept the call that creates negative perception towards the so-called nonnative English teachers themselves. It is important to note that "the notion of the native speaker, and all the linguistic, social, and economic connotations that accompany it, are troublesome and open to controversy' (Braine, 2010). According to Llurda (2016), this two-great group classification of native and nonnative speakers clearly resembles the common division between 'us' and 'the others' present in those communities which try to its 'true members', thus preventing 'the others' from fully participating in the community activities. In that kind of classification, he refers the native speakers as 'us' and the nonnative speakers as 'the others'.

This act of classifying speakers of a language as 'the others', in fact has been a root of many employment discrimination practices. Nonnative teachers of English have been treated unfairly in the hiring recruitment because of the wrong perception of either those who have enjoyed the 'nativeness' of English or others who have fallen into 'the native speaker fallacy', a famous phrase introduced by Phillipson (1992) to refer to the unfair treatment of qualified NNESTs. 'Native' teachers that refer to people from what Kachru (1986) terms as inner circle countries will very easily obtain well-paid jobs in Language teaching profession and form big industries in the language area because of the native-speaker model in ELT pedagogy. This model is even clearly unjustified when these 'native' teachers have never been trained to teach English to say that they are employed merely because of their 'Nativeness' in English. Wang \& Ling (2013) reported that NESTs are prioritized in Hongkong without requirements of teaching qualifications and experience.

Others who have fallen into the native speaker fallacy are those bilingual users of English from Kachru's distinction of either the outer or expanding circle countries. Several cases show the evidence towards this issue. Native English speakers without teaching qualification are more likely to be hired as ESL teachers than qualified and experienced onnative-English-speaking Teachers, especially outside the United States. It is 
a famous notion that the ideal teacher of English is a native speaker so that English competence is viewed as the competence of native speakers (Sharifian, 2013). Alsagoff et al (2012) support the claim that discrimination in ELT professionalism tends to be racist when the persona of NEST is just connected to the whites through the findings in their research revealing that some EFL/ESL institutes only hire the white NEST. Saengngoen (2014) also found this practice in the advertisements of the English teacher recruitments in Malaysia, Thailand, and Taiwan which obviously announced the nationalities as the requirement. The nationalities of the prospective candidates include those western countries to mention USA, UK, Canada, Australia, and New Zealand. Mahboob and Golden (2013) also found in their study that nationality played an important factor of discrimination for NNESTs, especially in East Asia and Middle East. It is certainly quite painful to know that those, who are in the same position of not coming from the countries of the inner circle, treat their own peers that way.

Unlike other Asian countries, such as China, Japan, Korea, and Thailand, where much of English language teaching is performed by Native English-speaking teachers, in Indonesia most of this teaching is undertaken by local teachers. Ismiyani (2021) shows the fact that Indonesian government has not prioritized this language learning as much as in China which somehow contributes to the condition of hiring NESTs for language teaching not being a big issue in the country. Although Ismiyani also claimed that the situation would restrain Indonesia to have their Indonesian English version, the involvement of local teachers in teaching English is indeed healthy and plays an important role in the ways Indonesian teachers of English perceive their identities, as they rarely face the native-nonnative dichotomy directly in their working environment.

In Indonesia, most teachers compete to each other from the same nationality background and the qualified ones will occupy the job position. It sounds quite fair, without explicitly saying that nonnative teachers in Indonesia are fairly treated. I also found that in Indonesia the native/nonnative distinction, even though it actually exists, does not seem to be a major problem in some extent. The majority of English teachers are local teachers. Being an English teacher is something that is prestigious in this country because those who speak English are considered to be more modern, educated, and well-informed to western culture and global world as also admitted by Tanner (in Karim \& Ismiyani, 2014). Tanner (in Karim \& Ismiyani, 2014) argued that English was accepted in Indonesia as "the mark of the well-educated man, a symbol of the new elite". For Indonesian people, English is considered as a language of modernization and technology development. For some exaggeration, when you tell them you speak English, they will see you as an excellent person because for them, learning English is very difficult. For Indonesian people, learning English words is difficult, not only because the tenses that really confuse them, but also the way in reading and pronouncing them. However, taking a deeper look inside Indonesia hiring system, one will still find the application from the dichotomy between native/nonnative teachers of English. There, only native speakers of English or those who are near-native in speaking English are hired in international and some prominent schools. And certainly, they are paid much higher than local teachers. Formerly, in big IELTS training programs, the native speakers especially those who were born and raised in the countries of 'whiteness', were the sole criteria of teachers to be hired, such as in Jakarta, Surabaya, and other big cities. However, it seems that the trend has slightly changed that any native speakers are allowed to teach in the institutions. Native speakers are not hired in ordinary schools because the schools will not afford to pay them.

The afflicting status of Nonnative-English-speaking teachers is, inevitably, a result of the embedded predicate of the calling term. Such predicate surely contributes to the identity of the so-called nonnative teachers of English. Nonnative speakers of a language mean that they are not the ones who are natives of the language. Obviously, the embedded 'non' call means that because they are not native so they do not possess a privilege as the natives of the language do. Such 'non' call surely creates an image that people would assume negatively. Meanwhile, the proper definition of a native speaker, according to Davies (1991), does not exist. Then, I strongly agree with what Braine (2010) argues that a similar claim could not be made for Nonnative 
speakers, too. Braine (2010) suggested the variety of terms which indicates the struggle for self-definition and the identity crisis that prevails among nonnative professionals, they are:

- Second language speaking professionals

- English teachers speaking other languages

- Nonnative speakers of English in TESOL

- Nonnative professionals in TESOL

- Nonnative teachers of English

- Nonnative English speaking professionals

- Second language teaching professionals

- Nonnative English teachers

Those calls or aliases sound better for me. However, I am personally still questioning five of the terms which still embed 'nonnative' on each call because their negative image would still reflect wrong perception towards the users. Since English is globalized, these bilingual teachers of English have also to be appreciated as the teachers of English as an international language and be made comfortable in their position by calling them in a more appropriate way.

In my own perspective, the real nonnative English teachers that people mean is also still a question. Are they just teachers whose English is not their first language? What about if they are bilingual since children? Their first language is not English, but they always speak English when they are outside because the society only uses English as a tool of communication, like in Australia. In that case, I can guaranty that their English must not be different from those of the so-called native speakers of English. And when these teachers are well trained, they will be highly qualified teachers of English. Or are the nonnative teachers of English including their look appearance that are not blonde-hair or blue-eyed? If so, how about those teachers who come from mixed parents, and only use English as their sole medium of communication? I do not think this kind of teachers can be called as nonnative teachers of English because they teach English where English is their own mother tongue. Or are nonnative English teachers those whose English is not their mother tongue and they learn English consciously because English is not spoken in the society? This kind of definition may apply for those who are from what Kachru defines as countries of the Expanding Circle. Meanwhile, those coming from what Kachru calls the Outer circle countries are also called nonnative teachers of English. Their first language is English, but they learn English consciously because English is officially spoken in the society. Furthermore, the terms offered by Braine (2010) lead me to a question of how actually nonnative teachers of English define themselves and in what term they want the world to call them.

The issue of nonnative-English-speaking teachers' identity is not less significant than that of the 'merely' users of English. Identity always involves multi sides of aspects of a person, whoever he/she is such as personal and cultural aspects. That is why, Meaning, which individuals construct, according to Phan (2016) is not only shaped by their cultural practices, but also reflects their own identities, for example, meanings constructed from gender, religion, or age perspective. As Hall (in Sadeghpour \& Sharifian, 2019) argues that identity is created through the production of meaning, which gives us a sense of identity, of who we are, and with whom we belong, Phan (2016) contended that therefore we have multiple identities, not just one identity. That is why I come to a decision that I can neglect the identity of the teachers of English in a matter of English Language teaching profession and focus more on their qualified English teaching competence.

\section{Actions for self-confidence of nonnative teachers of english as an international language}

To define, Nonnative teachers of English are teachers whose mother tongue is not English and learn English consciously as their other languages. Such definition is made to avoid misperception that brown skin looks are always nonnative. Some people may confuse the term for a nonnative look that was born and grown up in an English-speaking country and speak English very fluently since s/he learn during his/her childhood. The notion of the native speaker, and all the linguistic, social, and economic connotations that accompany it, 
are troublesome and open to controversy' (Braine, 2010). This proves that the dichotomy terms of 'native' vs 'nonnative' of English are somehow rather confusing.

Nonnative teachers are already claimed to be less-proficient users of English and the proficiency in teaching this language is also being inevitably questioned. These nonnative-English-speaking teachers (NNESTs) obviously cannot just let this treatment continue to happen. They need to prove that they deserve equal treatments as native-English-speaking teachers of English. In fact NNESTs have bright sides that their Native colleagues do not have in common which can create conducive English teaching learning.

Nonnative teachers of English are said to have a tendency to suffer from schizophrenia and an inferiority complex (Medgyes in Fithriani, 2018). When NNESTs suffer from schizophrenia, they tend to carry the English language and its culture over in their first language and private life. For example, these kinds of teachers follow exactly how the westerners dress or imitate these native English speakers' style which is frequently not matched to their culture or even religion.

Meanwhile, when NNESTs experience from an inferiority complex, Medgyes (in Fithriani, 2018) stated that they are in constant distress as they realize how little they know about the language they are going to teach. In this problem, what Llurda (2016) suggests may be a good solution for NNESTs. She proposes that NNESTs need to develop a high level of what it means to teach a language in order to avoid wrong practices in ELT teaching practice. To start with, they need to get involved in reading and discussion which critically discuss the implications of English as an International Language (EIL). These activities shall help the NNESTs avoid the misperception in teaching English and not suffer from identity crisis which cause the two abnormal behaviors namely schizophrenia and inferiority complex. Furthermore, to socialize EIL to NNESTs and engaging them in promoting a vision to use different varieties of English as what Llurda (2016) has also suggested may play a crucial role toward this issue.

The above clarification of the dark sides of being nonnative teachers of English may somehow yield a disappointment in English teaching profession. However, these teachers in fact have a number of bright sides to be their strengths in succeeding the English language learning and teaching. According to Medges (in Fithriani, 2018), one of the bright sides of being NNESTs is that they could provide a good model for imitation. Students definitely need a model to be imitated. A successful teacher is a successful learner of English. The teacher can transfer the knowledge and experience s/he received during acquiring the language to the students. The students can be encouraged to learn English successfully as they get the model from their teacher. However, if the students perceive that the teacher is not qualified or they feel difficulty in understanding the teacher's method of teaching, they will conversely be discouraged in learning English.

An action that can be suggested to deal with this matter is that NNESTs need to have a great number of opportunities to develop their language skills. According to Llurda (2016), one of the ways is that NNESTs have to be exposed to the target language long enough as to feel comfortable in speaking it. Sending them to some English speaking countries or providing them with some English language and teaching programs to encourage them to speak English more frequently to achieve good fluency as well as to gain more knowledge about ELT may be relevant ideas to improve their ELT competence.

The other positive side of being the so-called nonnative teachers of English is that they were found to be more insightful than native-English-speaking teachers because of their differences in the process of mastering the English language (Medgyes in Fithriani, 2018). Because NNESTs acquire English consciously, they must be aware of the internal mechanism operating the language use that they can give their students relevant information about language learning. Teaching how to use gerund in English grammar is one of the abundant examples. There was an interesting experience from the writer when attending a language preparatory class in her country taught by a native speaker from South Africa with New Zealander blood, one of her classmates asked why after 'of' in a phrase 'a way of thinking' is followed by thinking and not think. After a few seconds confusing the class with some unclear reasons, he finally offered the class to help him explain it. One of the participants who was fortunately a nonnative teacher of English raised his hand and 
explained it with good reason that the native instructor said it was true and admitted that he just realized it. This kind of real experience might convince us that nonnative teachers of English expedite the process of language learning.

According to Medgyes (in Fithriani, 2018; Sadeghpour \& Sharifian, 2019), NNESTs benefit from the mother tongue. They can use their students' mother tongue to explain the language use that the students may hardly understand. The proper use of mother tongue surely could save the class time. However, NNESTs only benefit from the mother tongue if they share the same first language with the students. When nonnative teachers of English teach English in another non-speaking English country, it will be hard to say that they can make use of their mother tongue to teach the students since they have different mother tongues. When this is the case, nonnative teachers definitely still can transfer their knowledge in learning English through English language. At least, NNESTs are admitted to have clearer and more understandable pronunciation than NESTs that their students can understand more easily.

Other studies with various methods of research are obviously needed to investigate further about the status of NNEST especially those whose born as "halved-natives" by the parents' blood and those who do not have 'native' blood of inner circle nations but born in the inner circle countries as well as the discrimination such as race and income gap made by NESTs and NNESTs. Nevertheless, this literature review has also uncovered the fact that discrimination in ELT industry is, although not all time, still racist; in other words, the industry gives employment opportunity to White people regardless their status as native- or non-native English speakers, and exclude those with colored complexion. This study also has proven that there is also a discrimination practice in financial aspect for NNESTs, who tend to receive lower pay than their counterparts.

\section{CONCLUSION}

We might need to reconsider to keep calling the bilingual teachers of English as 'nonnative teachers of English'. Calling ones for what they are not creates a distance that makes the so-called nonnative teachers fail to gain equal treatment in ELT profession. Identity is needed, but quality has to be the main qualification in ELT work field. Having experiences in English speaking countries or joining language and teaching programs may improve NNESTs' language competence. If they feel that they are competent in the language, they will have self-confidence to teach in any parts of the world. One critical action to perform is to socialize English as an International Language as to create conducive learning and teaching process of English and contribute greatly to NNESTs' self-confidence because they know that the varieties of English they are speaking and teaching are accepted and desirable in this world. Kachru, the father of World Englishes has suggested that it is time for a paradigm shift which takes into accounts the changing roles and functions of English around the world in linguistic research and in language pedagogy.

\section{REFERENCES}

Ahn, H. (2013). English Policy In South Korea: A Role In Attaining Global Competitiveness Or A Vehicle Of Social Mobility? Journal Of English As An International Language, 8(1), 1-20. Http://Asian-EflJournal.Com/Eilj/Wp-Content/Uploads/2013/12/Eilj2013_May2013.Pdf

Alsagoff, L., Mckay, S., Hu, G., \& Renandya, W. (2012). No Title. In Principles And Practices For Teaching English As An International Language. New York/London: Routledge.

Braine, G. (2010). Non-Native Speaker English Teachers: Research, Pedagogy, And Professional Growth. New York: Routledge.

Fithriani, R. (2018). Discrimination Behind Nest And Nnest Dichotomy In ELT Pofesionalism. Kne Social Sciences, 3(4), 741-755. Https://Doi.Org/Https://Doi.Org/10.18502/Kss.V3i4.1982 
4539 The Future of Nonnative Teachers of English - Nining Ismiyani DOI: https://doi.org/10.31004/edukatif.v3i6.1243

Ismiyani, N. (2021). Who Owns English ?: Interviews To The Indonesians. Jurnal Ilmu Pendidikan, 3(5), 2232-2239. Https://Doi.Org/Https://Doi.Org/10.31004/Edukatif.V3i5.570

Kachru, B. (1986). The Alchemy Of English: The Spread, Functions, And Models Of Non-Native Englishes. Oxford, England: Pergamon.

Karim, N. S. A., \& Ismiyani, N. (2014). Academic And Prestige: Indonesian Lecturers' Attitudes Towards TOEFL. Journal of English As An International Language, 9(1), 104-120. Https://Www.Eilj.Com/Journals/Volume-9-Issue-1-May-2014/

Kasai, M., Lee, J. A., \& Kim, S. (2011). Secondary EFL Students' Perceptions Of Native And Nonnative English-Speaking Teachers In Japan And Korea. Asian EFL Journal, 13(3), 272-300.

Khatib, M., \& Monfared, A. (2017). Exploring Teachers' Attitudes Towards Pronunciation Issues And Varieties Of English In Three Circles World Englishes. Applied Research On English Language, 6(2), 213-236. Https://Www.Noormags.Ir/View/En/Articlepage/76585/227/Text

Kurniawati, K., \& Rizki, D. (2018). Native Vs. Non-Native EFL Teachers: Who Are Better? Studies In English Language And Education, 5(1), 137-147. Https://Doi.Org/10.24815/Siele.V5i1.9432

Llurda, E. (2016). 'Native Speakers', English And ELT: Changing Perspectives. In The Routledge Handbook Of English Language Teaching (Pp. 69-81). Routledge.

Mahboob, A., \& Golden, R. (2013). Looking For Native Speakers Of English: Discrimination In English Language Teaching Job Advertisements. Voices In Asia Journal, 1(1), 72-81. Https://Www.Academia.Edu/4517679/Looking_For_Native_Speakers_Of_English_Discrimination_In_ English_Language_Teaching_Job_Advertisements

Mauludin, L. A. (2015). The Importance Of Non-Native English Speaker Teachers In The Context Of English As A Foreign Language. Transformatika, 11(2), 134-144.

Nguyen, M. X. N. C. (2017). TESOL Teachers' Engagement With The Native Speaker Model: How Does Teacher Education Impact On Their Beliefs? RELC Journal, 48(1), 83-98. Https://Doi.Org/Https://Doi.Org/10.1177/0033688217690066

Phan, N. L. H. (2016). English As An International Language (EIL) In Vietnam: A Study Of Vietnamese ELT Teachers' Reflections. Monash University, Melbourne.

Phillipson, R. (1992). Linguistic Imperialism. Oxford: Oxford University Press.

Publishing With Us - Routledge. (2016). Taylor \& Francis Group. Https://Www.Routledge.Com/OurCustomers/Authors/Why-Publish-With-Us

Sadeghpour, M., \& Sharifian, F. (2019). World Englishes In English Language Teaching. World Englishes, 38, 245-258 (Special Issue In Memory Of Braj Kachru). Https://Doi.Org/DOI:10.1111/Weng.12372

Saengngoen, J. (2014). Native-Speakerism: Non-White And Non-Native English Teachers In The ESL/EFL Field With A Focus On Thailand And Southeast Asia. Unpublished Manuscript, Department Of Language, Literacy, And Sociocultural Studies, University Of New Mexico, Albuquerque, USA.

Sharifian, F. (2013). Globalisation And Developing Metacultural Competence In Learning English As An International Language. Multiligual Education, 3(7). Https://Doi.Org/Https://Doi.Org/10.1186/21915059-3-7

Sharifian, F. (2014). Teaching English As An International Language In Multicultural Contexts: Focus On Australia. In R. Mar-Lina \& R. A. Giri (Eds.). In The Pedagogy Of English As An International Language: Perspectives From Scholars, Teachers, And Students (Vol. 1, Pp. 35-46). Springer, Cham. Https://Doi.Org/Https://Doi.Org/10.1007/978-3-319-06127-6_3

Sun, Y. (2014). Major Trends In The Global ELT Field: A Non-Native English-Speaking Professional's Perspective. Language Education In Asia, 5, 7-19. Https://Doi.Org/10.5746/LEIA/14/V5/I1/A02/SUN

Tajeddin, Z., \& Adeh, A. (2016). Native And Nonnative English Teachers' Perceptions Of Their Professional Identity: Convergent Or Divergent? Iranian Journal Of Language Teaching Research, 4(3), 37-54. 
4540 The Future of Nonnative Teachers of English - Nining Ismiyani

DOI: https://doi.org/10.31004/edukatif.v3i6.1243

Tsou, S.-Y., \& Chen, Y. (2019). No Title. International Journal Of Teaching And Learning In Higher Education, $31(2)$,

$176-183$

Https://Www.Google.Com/Url?Sa=T\&Rct=J\&Q=\&Esrc=S\&Source=Web\&Cd=\&Ved=2ahukewjy27wk sadzahww7xmbhv1ma_8qfnoecamqaq\&Url=Https\%3A\%2F\%2Ffiles.Eric.Ed.Gov\%2Ffulltext\%2FEJ12 24432.Pdf\&Usg=Aovvaw120-Tieeejyfc2kaof1 ydw

Wang, L.-Y., \& Lin, T.-B. (2013). The Representation Of Professionalism In Native English-Speaking Teachers Recruitment Policies: A Comparative Study Of Hong Kong, Japan, Korea And Taiwan. English Teaching: Practice And Critique, 12(3), 5-22. Http://Education.Waikato.Ac.Nz/Research/Files/Etpc/Files/2013v12n3art1.Pdf 